\title{
REDESAIN SISTEM ELEKTRIKAL STADION CITARUM (BAGIAN SISTEM PROTEKSI PETIR)
}

\author{
Vaneza Cindy Yolanda*), Karnoto dan Hermawan \\ Departemen Teknik Elektro, Universitas Diponegoro \\ Jl. Prof. Sudharto, SH, Kampus UNDIP Tembalang, Semarang 50275, Indonesia \\ ${ }^{*}$ E-mail:cindyvaneza17@@gmail.com
}

\begin{abstract}
Abstrak
Aspek keamanan, kenyamanan dan keselamatan menjadi salah satu faktor untuk mengukur tingkat kelayakan dari Stadion Citarum. Fenomena petir merupakan hal yang patut diperhatikan untuk keselamatan pengguna di Stadion Citarum. Stadion merupakan bangunan yang memerlukan pemasangan sistem proteksi petir karena potensi bahaya akibat sambaran petir. Sistem proteksi petir yang belum memadai mendasari dilakukannya perancangan sistem proteksi petir untuk melindungi bangunan Stadion Citarum. Prosedur perhitungan sistem proteksi petir eksternal menggunakan standar IEC 62305-3, menggunakan radius Rolling Sphere, besar sudut Protection Angle dan lebar Mesh yang mengacu pada standar SNI 03-7015-2004. Sistem proteksi internal ditentukan berdasar kelas arrester/Surge Protective Device, dimana tegangan sisa yang masuk nilainya tidak boleh melebihi BIL Peralatan sebesar 2kV sesuai standar SNI 04-7021.21-2004. Penelitian ini menunjukkan hasil simulasi metode Rolling Sphere memiliki area perlindungan paling baik, dengan radius 60 meter pada bangunan tribun menunjukkan bahwa air terminal yang terpasang sudah melindungi bangunan. Sistem proteksi petir internal menggunakan arrester / Surge Protective Device pada kelas 2.
\end{abstract}

Kata kunci: Petir, Sistem Proteksi Petir, Rolling Sphere, Protection Angle, Mesh, Surge Protective Device

\begin{abstract}
The aspect of security, comfort and safety is one of the factors to measure the level of feasibility of the Citarum Stadium. Lightning phenomenon is something that is noteworthy for the safety of users at the Citarum Stadium. The stadium is a building that requires the installation of a lightning protection system because of the potential danger due to lightning strikes. An inadequate lightning protection system underlies the design of a lightning protection system to protect the Citarum Stadium building. The procedure for calculating an external lightning protection system uses the IEC 62305-3 standard, using a Rolling Sphere radius, a large angle of Protection Angle and Mesh width which refers to SNI 03-70152004 standard. The internal protection system is determined based on the class of arrester / Surge Protective Device, where the remaining residual stress value cannot exceed the Equipment BIL of 2kV according to SNI 04-7021.21-2004 standard. This study shows the results of the Rolling Sphere method simulation have the best protection area, with a radius of 60 meters in the building of the stands shows that the installed terminal water has protected the building. Internal lightning protection system uses arrester / Surge Protective Device in class 2.
\end{abstract}

Keywords: Lightning, Lightning Protection System, Rolling Sphere, Protection Angle, Mesh, Surge Protective Device

\section{Pendahuluan}

Aspek keamanan, kenyamanan dan keselamatan menjadi salah satu faktor untuk mengukur tingkat kelayakan dari Stadion Citarum. Salah satu hal yang patut diperhatikan untuk keselamatan pengguna dan penonton di Stadion Citarum adalah fenomena petir. Stadion merupakan salah satu bangunan yang perlu dilakukan pemasangan sistem proteksi petir karena potensi bahaya yang dapat ditimbulkan akibat sambaran petir.

Petir merupakan fenomena alam dimana terjadi loncatan muatan listrik antara awan dengan bumi karena perbedaan potensial antara awan dengan bumi yang besar[1]. Potensi terjadinya petir dapat dihitung berdasarkan jumlah hari guruh dalam satu tahun di suatu wilayah yaitu garis pada peta yang menghubungkan daerah-daerah dengan rata-rata jumlah hari guruh yang sama disebut dengan Isokeraunik Level (IKL)[2]. Berdasarkan data Stasiun Geofisika Banjarnegara untuk wilayah Semarang memiliki hari guruh sebesar $40.63 \%$ dengan tingkat curah petir sebanyak 148[3]. Sambaran langsung dapat menyebabkan kerusakan pada bangunan, peralatan, bahkan korban jiwa[4]. tegangan lebih induksi yang disebabkan sambaran petir tidak langsung dapat mempengaruhi kinerja, bahkan 
kerusakan peralatan. Hal tersebut dapat menimbulkan kerugian yang sangat besar, sehingga dibutuhkan usaha untuk mengurangi resiko kerusakan akibat sambaran petir terlebih untuk bangunan penting, yaitu dengan sistem proteksi petir[5].

Sistem protesi petir eksternal untuk meminimalisir terjadinya gangguan dan kerugian akibat sambaran petir. Perancangan proteksi petir ini dilakukan dengan menggunakan metode Rolling Sphere, Protection Angle dan Mesh. Sedangkan pada sistem proteksi petir internal dengan pemilihan kelas arrester yang akan digunakan

\section{Metode}

\subsection{Langkah Penelitian}

Gambar 1 menunjukan diagram alir sistem proteksi petir eksternal dan sistem proteksi petir internal

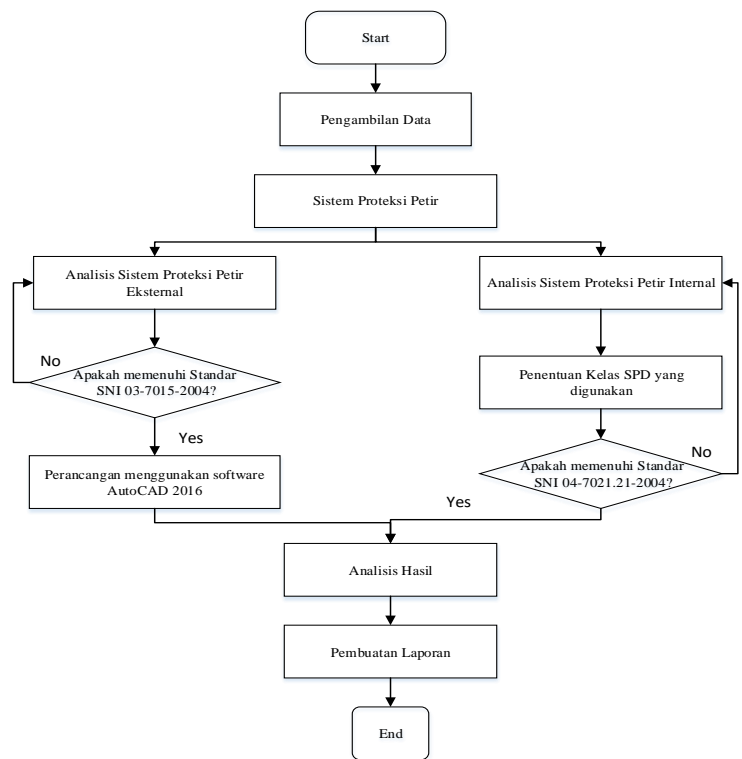

Gambar 1. Diagram Alir Langkah Penelitian

\subsection{Pengumpulan Data}

Data-data teknis penelitian diperoleh berdasarkan survey yang telah dilakukan di Stadion Citarum Semarang.

Tabel 1. Efisiensi Sistem Proteksi Petir (SPP)

\begin{tabular}{lllll}
\hline Bangunan & $\begin{array}{l}\text { Panjang } \\
(\mathbf{m})\end{array}$ & $\begin{array}{l}\text { Lebar } \\
(\mathbf{m})\end{array}$ & $\begin{array}{l}\text { Tinggi } \\
(\mathbf{m})\end{array}$ & $\begin{array}{l}\text { Tahanan } \\
\text { Tanah }\end{array}$ \\
\hline Tribun Barat & 107,50 & 16,25 & 14,92 & $18,6 \Omega$ \\
$\begin{array}{l}\text { Tribun } \\
\text { Timur }\end{array}$ & 107,50 & 12.95 & 12,92 & $18,6 \Omega$ \\
$\begin{array}{l}\text { Tribun Utara } \\
\text { Tribun }\end{array}$ & 71 & 8,32 & 8,59 & $18,6 \Omega$ \\
Selatan & 71 & 8,32 & 8,59 & $18,6 \Omega$ \\
Tiang Lampu & 6,30 & 0,59 & 28 & $18,6 \Omega$ \\
\hline
\end{tabular}

\subsection{Penentuan Taksiran Risiko}

Perhitungan taksiran risiko dipakai untuk menentukan level proteksi yang harus dipakai pada metode rolling sphere dan protection angle[7].

$I K L=\frac{T d}{365} \times 100 \%$

$N g=0,04 \cdot T_{d}^{1,25}$

Dimana,

$\mathrm{Ng}=$ Kerapatan sambaran petir ke tanah (sambaran $/ \mathrm{Km}^{2} /$ tahun )

$\mathrm{T}_{\mathrm{d}} \quad=$ Hari guruh rata-rata pertahun

$N d=N g \cdot A e \cdot 10^{-6}$

Dimana,

$\mathrm{Nd}=$ Frekuensi sambaran petir langsung per tahun $\mathrm{Nc}$

$A e=a b+6 h(a+b)+9 . \pi h^{2}$

Dimana,

$$
\begin{array}{ll}
\mathrm{a} & =\text { Panjang atap gedung }(\mathrm{m}) \\
\mathrm{b} & =\text { Lebar atap gedung }(\mathrm{m}) \\
\mathrm{h} & =\text { Tinggi atap gedung }(\mathrm{m}) \\
\mathrm{Ae} & =\text { Area Cakupan dari Struktur }\left(\mathrm{m}^{2}\right)
\end{array}
$$

Pengambilan keputusan perlu atau tidaknya memasang sistem proteksi dilakukan dengan ketentuan sebagai berikut :

- Jika $\mathrm{Nd} \leq \mathrm{Nc}$ tidak perlu sistem proteksi petir.

- Jika Nd > Nc diperlukan sistem proteksi petir.

Penentuan tingkat proteksi petir dilakukan berdasakan nilai efisiensi sebagai berikut :

$E \geq 1-\frac{N c}{N d}$

Dimana,

$\mathrm{E} \quad=$ Efisiensi sistem proteksi petir .

$\mathrm{Nc} \quad=$ Frekuensi sambaran petir tahunan yang diperbolehkan $\left(10^{-1}\right)$.

$\mathrm{Nd} \quad=$ Frekuensi sambaran petir langsung per tahun

Tabel 2. Efisiensi Sistem Proteksi Petir (SPP)

\begin{tabular}{lcc}
\hline $\begin{array}{l}\text { Class of Lightning } \\
\text { Level (LPS) }\end{array}$ & Protection & $\begin{array}{c}\text { Efisiensi SPP (E) } \\
(\boldsymbol{\%})\end{array}$ \\
\hline & I & 98 \\
II & 95 \\
III & 90 \\
IV & 80 \\
\hline
\end{tabular}

\subsection{Beban Korosi}

Proses elektrokimia karena pengosongan muatan awan. Proses elektrokimia yang timbul berupa pelelehan logam disekitar objek sambaran. Tingkat pelelehan logam dapat dinyatakan dalam persamaan (6) sebagai berikut[5]:

$$
v=\frac{w}{\gamma(C w(\theta s-\theta u)+C s)}
$$

Keterangan :

$$
=\text { volume pelelehan logam }\left(\mathrm{m}^{3}\right)
$$




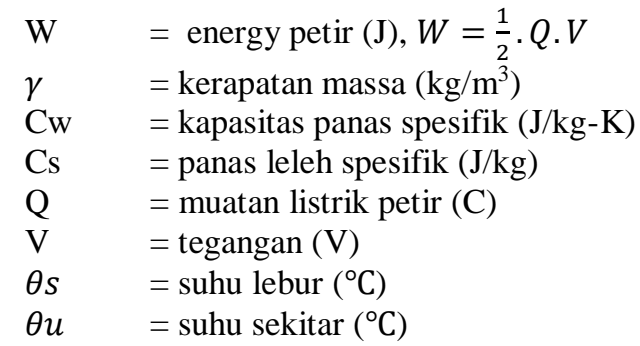

Untuk menghitung tahanan tanah menggunakan persamaan berikut :

Keterangan :

$$
R_{b t}=\frac{\rho}{2 \pi L} \ln \left(\frac{4 L}{\mathrm{~d}}-1\right)
$$

$$
\begin{array}{ll}
\mathrm{R}_{\mathrm{bt}} & =\text { Tahanan tanah }(\Omega) \\
\rho & =\text { tahanan jenis tanah }(\Omega \mathrm{m}) \\
L & =\text { panjang elektroda yang ditanam } \\
(\mathrm{m}) & \\
\mathrm{d} & =\text { diameter elektroda batang }(\mathrm{m})
\end{array}
$$

\subsection{Gelombang Berjalan}

Bila gelombang berjalan menemui titik peralihan, atau adanya perubahan impedansi maka, maka sebagian gelombang akan dipantulkan dan akan diteruskan ke bagian lain dari titik tersebut. Gelombang yang datang dinamakan incident wave $\left(e_{1}\right)$, gelombang yang dipantulkan dinamakan reflected wave $\left(e_{1}^{\prime}\right)$ dan gelombang terusan dinamakan transmitted wave $\left(e_{1}{ }^{\prime \prime}\right)$ seperti yang ditunjukkan pada Gambar 2.17.

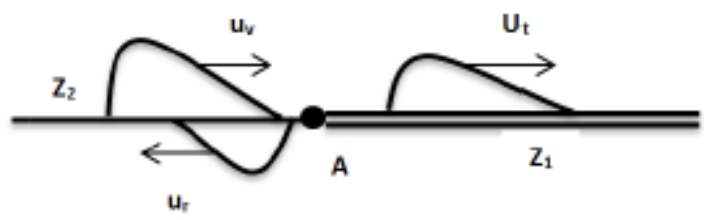

Gambar 2. Pantulan dan Terusan Gelombang Berjalan

Persimpangan tegangan dan arus terjadi pada titik A dimana terdapat perbedaan impedansi (Z1) pada sisi kiri dan impedansi (Z2) pada sisi kanan. Pada titik persimpangan A akan berlaku persamaan tegangan. Nilai gelombang tegangan pantulan dapat diketahui menggunakan persamaan:

$$
e_{1}^{\prime}=\frac{Z_{0-} Z_{1}}{Z_{0+} Z_{1}} e_{1}
$$

Koefisien pantulan untuk tegangan menggunakan persamaan :

$$
v_{1}=\frac{Z_{0-} Z_{1}}{Z_{0+} Z_{1}}
$$

Koefisien terusan untuk tegangan menggunakan persamaan :

$$
v_{2}=\frac{2 Z_{0}}{Z_{0+} Z_{1}}
$$

Gelombang tegangan terusan didapatkan dengan persamaan :

$$
e_{0}=\frac{2 Z_{0}}{Z_{0+} Z_{1}} e_{1}
$$

Koefisien terusan untuk tegangan ditinjau dari jumlah cabang saluran dapat diketahui dengan persamaan :

$$
T=\frac{2}{n}
$$

Jika gelombang datang dari satu cabang sampai di titik percabangan, gelombang akan diteruskan ke $\mathrm{n}-1$ cabang lain, dengan total impedansi ekivalennya sebesar,

$$
Z_{1(\text { ekivalen })}=\frac{Z_{1}}{n-1}
$$

Maka besar gelombang yang diteruskan sebesar,

$$
e_{1}^{\prime \prime}=T \cdot v_{i}
$$

\subsection{Pengolahan Data}

Pengolahan data dilakukan dengan menghitung jumlah air terminal, jarak antar air terminal, jumlah down conductor, dan jarak down conductor dengan metode rolling sphere, protection angle dan mesh berdasarkan standar SNI 037015-2004 untuk sistem proteksi eksternal, serta dilakukan perkiraan volume pelelehan konduktor pembumian yang dapat terjadi. Sistem proteksi petir internal dihitung berdasarkan klasifikasi kelas arrester yang akan dipasang berdasarkan BIL peralatan yang mengacu pada standar SNI 04-7021.21-2004

\subsection{Perancangan Penempatan External Lightning Protection}

Hasil pegolahan data kemudian dijadikan sebagai acuan dalam perancangan penempatan sistem proteksi petir (SPP) eksternal pada bangunan Stadion Citarum. Perancangan dilakukan menggunakan perangkat lunak AutoCad 2016 dengan menggambarkan area proteksi petir pada gedung berdasarkan metode rolling sphere, protection angle dan mesh.

\subsection{Perhitungan Sistem Proteksi Petir Internal}

Dilakukan perhitungan gelombang tegangan berjalan yang dapat masuk dan dapat berakibat merusak peralatan. Sehingga dapat menentukan kelas Surge Protection Device yang sesuai dengan lokasi pemasangannya. Setelah ditentukan kelas SPD yang digunakan, menghitung tegangan residu yang masuk ke peralatan dimana nilainya tidak boleh melebihi BIL peralatan sesuai standar SNI 047021.21-2004 yaitu $2 \mathrm{kV}$ [7].

\section{Hasil dan Analisis \\ 3.1. Penentuan Taksiran Risiko}

Perhitungan diawali dengan menghitung taksiran resiko untuk menentukan level proteksi yang harus dipakai pada metode rolling sphere dan protection angle.[7]

Dari tabel 3 diketahui diketahui bahwa nilai efisiensi menentukan tingkat proteksi petir yang akan diterapkan. Tribun Barat memiliki nilai $\mathrm{E} \geq 74,66 \%$, tribun timur memiliki nilai $\mathrm{E} \geq 68,64 \%$, serta tribun utara dan selatan 
masing-masing memiliki nilai efisiensi sebesar $\mathrm{E} \geq 28,40 \%$. Sedangkan tiang lampu memiliki efisiensi $\mathrm{E} \geq 86,08 \%$ Berdasarkan tabel 3 nilai efisiensi $0 \%<\mathrm{E} \leq 80 \%$ berada pada level proteksi IV. Sehingga Tribun Barat, Utara, Timur, dan Selatan menggunakan sistem proteksi petir (SPP) kelas IV yang memiliki radius perlindungan 60 meter dengan sudut proteksi sebesar 55०[5] dan pada tiang lampu menggunakan level proteksi kelas III dengan radius perlindungan 45 meter dengan sudut proteksi 45०.[5]

Tabel 3. Hasil Perhitungan Taksiran Resiko

\begin{tabular}{lcccccc}
\hline Bangunan & Td & $\mathbf{N g}$ & $\mathbf{A e}\left(\mathbf{m}^{2}\right)$ & $\mathbf{N d}$ & $\mathbf{N c}$ & $\mathbf{E}(\%)$ \\
\hline $\begin{array}{l}\text { Tribun Barat } \\
\text { Tribun }\end{array}$ & 148 & 20.64 & 19115,83 & 0,394 & 0,1 & 74,66 \\
$\begin{array}{l}\text { Utara } \\
\text { Tribun }\end{array}$ & 148 & 20.64 & 6764,12 & 0,139 & 0,1 & 28,40 \\
$\begin{array}{l}\text { TImur } \\
\text { Tribun } \\
\text { Selatan }\end{array}$ & 148 & 20.64 & 15446,74 & 0,318 & 0,1 & 68,64 \\
$\begin{array}{l}\text { Tiang } \\
\text { Lampui }\end{array}$ & 148 & 20.64 & 6764,12 & 0,139 & 0,1 & 28,40 \\
& 148 & 20.64 & 34807,7 & 0,718 & 0,1 & 86,08 \\
\hline
\end{tabular}

\subsection{Perancangan external lightning protection dengan metode Rolling Sphere}

Dari hasil perhitungan didapat jumlah air terminal dan down conductor yang dipasang pada bangunan di Stadion Citarum adalah sebagai berikut :

Tabel 4. Hasil Perhitungan dengan Metode Rolling Sphere

\begin{tabular}{lclllll}
\hline Bangunan & $\begin{array}{c}\mathbf{p} \\
(\mathbf{m})\end{array}$ & $\begin{array}{l}\mathbf{d}_{\text {maxAT }} \\
(\mathbf{m})\end{array}$ & $\mathbf{N}_{\mathbf{D C}}$ & $\begin{array}{l}\mathbf{d}_{\mathbf{D C}} \\
(\mathbf{m})\end{array}$ & $\mathbf{N}_{\mathbf{A T}}$ & $\begin{array}{l}\mathbf{d}_{\mathbf{A T}} \\
(\mathbf{m})\end{array}$ \\
\hline Tribun Barat & 0,37 & 37,46 & 13 & 20 & 9 & 13,43 \\
\hline Tribun Utara & 0,66 & 37,46 & 8 & 20 & 5 & 17,75 \\
Tribun TImur & 0,37 & 37,46 & 12 & 20 & 9 & 13,43 \\
Tribun & 0,66 & 37,46 & 8 & 20 & 5 & 17.75 \\
Selatan & & & & & \\
Tiang Lampui & 0,02 & 32,31 & 2 & 15 & 2 & 6,30 \\
\hline
\end{tabular}

Keterangan :

$\mathrm{N}_{\mathrm{DC}} \quad$ : jumlah down conductor total

$\mathrm{N}_{\mathrm{AT}} \quad$ : jumlah air terminal total

$d_{D C} \quad$ : jarak antar down conductor

$d_{A T} \quad$ : jarak antar air terminal

$p \quad$ : jarak penetrasi

$d_{\max A T} \quad$ : jarak maksimal antar air terminal

Tabel 5. Volume kabel konduktor pembumian

\begin{tabular}{cccc}
\hline Lokasi & $\begin{array}{c}\text { Luas Penampang } \\
\left.\text { Konduktor( } \mathbf{c m}^{\mathbf{2}}\right)\end{array}$ & Panjang(m) & Volume $\left(\mathbf{c m}^{\mathbf{3}}\right)$ \\
\hline $\begin{array}{c}\text { Tribun } \\
\text { Barat }\end{array}$ & 1,85 & 116,55 & 21561,75 \\
Tribun & 1,85 & 37,10 & 6863,5 \\
Utara & 1,85 & 102,78 & 19014,3 \\
Tribun & 1,85 & 37,10 & 6863,5 \\
Timur & 1,85 & 70 & 12950 \\
Tribun & & & \\
$\begin{array}{c}\text { Selatan } \\
\text { Tiang }\end{array}$ & & & \\
Lampu & & &
\end{tabular}

Berdasarkan jumah down conductor yang menuju ke titik pembumian dapat diketahui volume pelelehan konduktor pembumian pada masing-masing bangunan tribun dan tiang lampu. Berdasarkan hasil perhitungan, dapat diketahui jika arus maksimum sebesar 100kA mampu membangkitkan efek korosi pelelehan logam pada masingmasing tribun sebesar $1095,47 \mathrm{~cm}^{3}$ pada tribun barat, $3154,71 \mathrm{~cm}^{3}$ pada tribun utara, $1095,45 \mathrm{~cm}^{3}$ pada tribun timur, dan $3154,71 \mathrm{~cm}^{3}$ pada tribun selatan. Sehingga dapat melelehkan sekitar 5,08\% dari total volume konduktor pembumian tribun barat, $45,96 \%$ dari total volume konduktor pembumian tribun utara, 5,76\% dari total volume konduktor pembumian tribun timur, dan $45,96 \%$ dari total konduktor pembumian tribun selatan. Sedangkan pada tiang lampu mampu membangkitkan efek korosi pelelehan logam sebesar 4390,02 $\mathrm{cm}^{3}$, dan dapat melelehkan $38,06 \%$ dari total volume konduktor pembumian tiang lampu. Untuk mengurangi dampak yang ditimbulkan dari efek pelelehan pada logam dapat menggunakan lapisan pelindung thermal dan anti korosi Perancangan sistem dilakukan dengan menggambar rancangan menggunakan AutoCAD 2016. Bangunan Stadion Citarum memiliki atap bangunan hanya pada tribun Barat, oleh karena itu selain pada tribun Barat, pada perancangan ini juga dilakukan perhitungan dan simulasi sistem proteksi petir dengan kondisi jika terdapat atap pada masing-masing tribun Utara, Timur dan Selatan.

Berdasarkan hasil perhitungan pada Tabel 4, diketahui pada Tribun Barat membutuhkan 27 air teminal, Tribun Utara membutuhkan penambahan 9 air teminal sehingga total berjumlah 27, Tribun selatan membutuhkan 10 air teminal.. Berikut ini gambar perancangan pemasangan air terminal dan down conductor dengan metode rolling sphere:

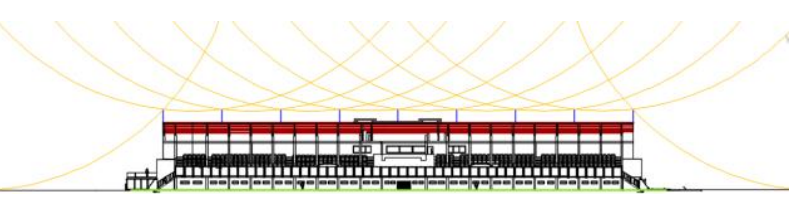

Gambar 3. Area perlindungan Metode Rolling Sphere pada Tribun Barat sisi panjang

Gambar 4. Area perlindungan Metode Rolling Sphere pada Tribun Barat sisi lebar

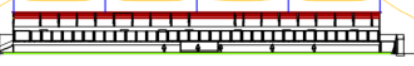

Gambar 5. Area perlindungan Metode Rolling Sphere pada Tribun Utara sisi panjang 


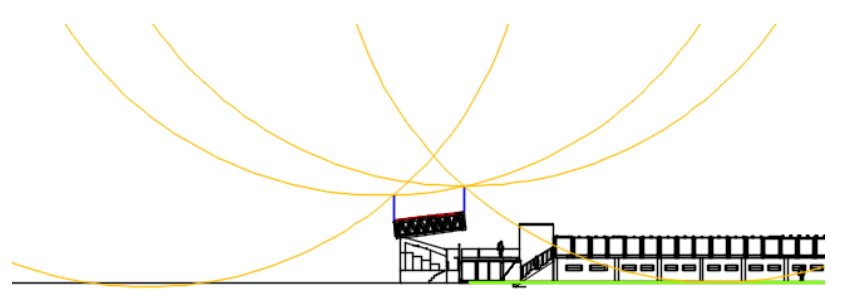

Gambar 6. Area perlindungan Metode Rolling Sphere pada Tribun Utara sisi lebar

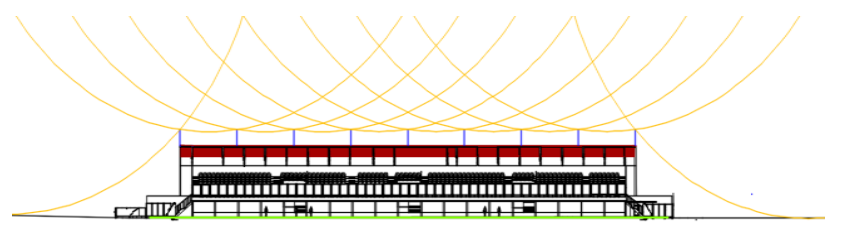

Gambar 7. Area perlindungan Metode Rolling Sphere pada Tribun Timur sisi panjang

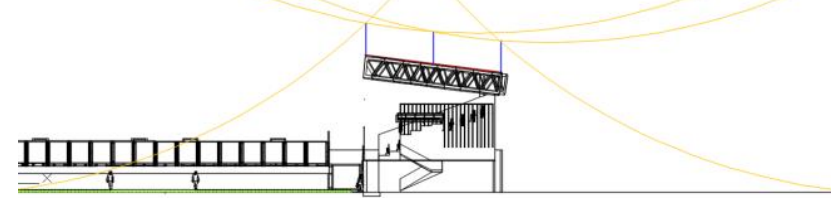

Gambar 8. Area perlindungan Metode Rolling Sphere pada Tribun Timur sisi lebar

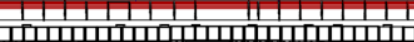

Gambar 9. Area perlindungan Metode Rolling Sphere pada Tribun Selatan sisi panjang

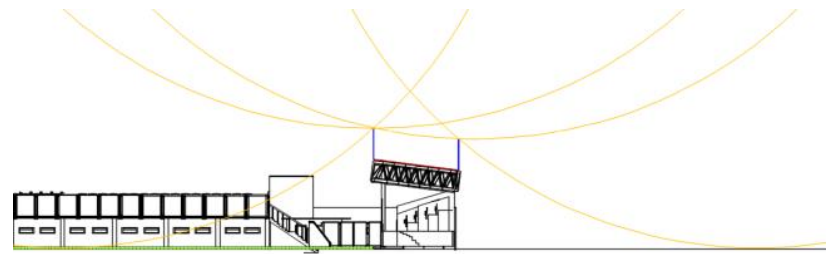

Gambar 10. Area perlindungan Metode Rolling Sphere pada Tribun Selatan sisi lebar

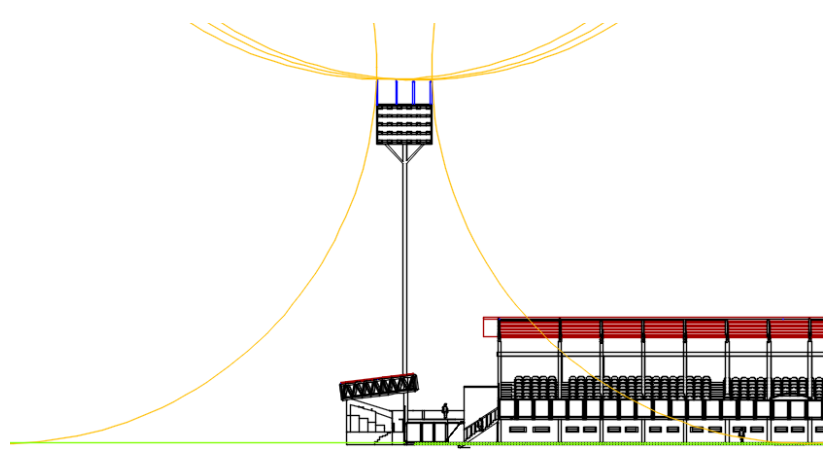

Gambar 11. Area perlindungan Metode Rolling Sphere pada Tiang Lampu

Berdasarkan hasil simulasi terlihat terdapat garis berwarna kuning yang merupakan garis khayal perlindungan rolling sphere, yang mana area dibawahnya merupakan area yang terlindungi, terlihat bahwa seluruh area tribun barat, utara, timur, selatan dan tiang lampu sudah terlindungi dan memenuhi standar SNI 03-7015-2004.

\subsection{Perancangan Sistem Proteksi Petir Eksternal Dengan Metode Protection Angle}

Perancangan sistem proteksi petir eksternal menggunakan metode Protection Angle mengacu pada standar SNI 037015-2004. Pada penentuan tingkat proteksi serta perhitungan jumlah down conductor dan air terminal sama dengan jumlah pada metode rolling sphere.Berikut ini hasil perancangan metode Protection Angle :

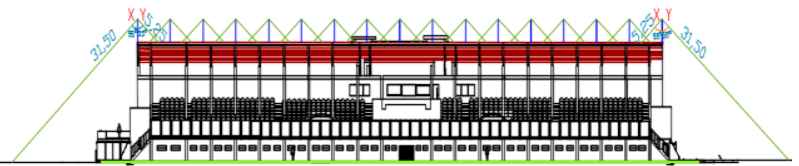

Gambar 12. Area perlindungan Metode Protection Angle pada Tribun Barat

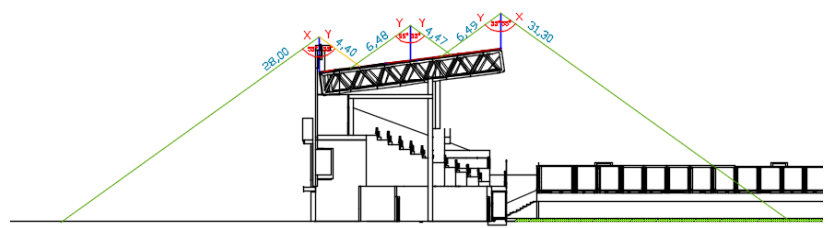

Gambar 13. Area perlindungan Metode Protection Angle pada Tribun Barat sisi lebar 


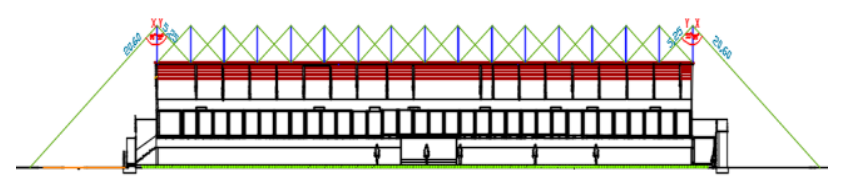

Gambar 14. Area perlindungan Metode Protection Angle pada Tribun Utara

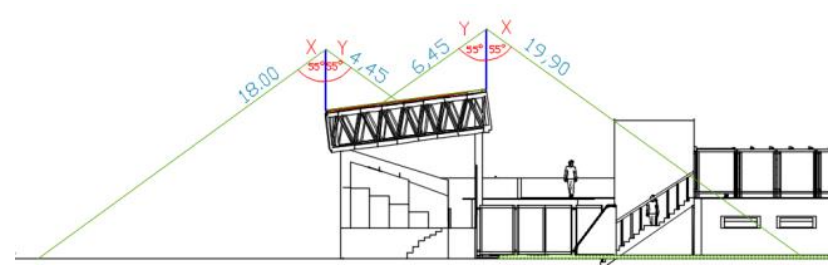

Gambar 15. Area perlindungan Metode Protection Angle pada Tribun Utara sisi lebar

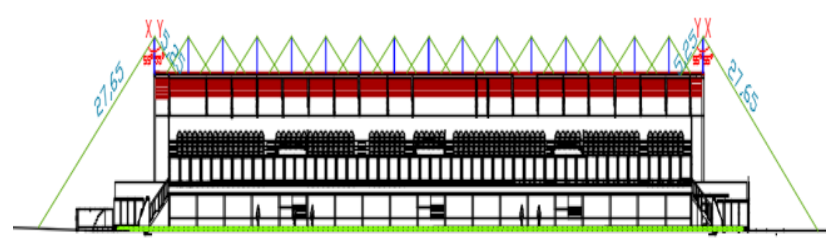

Gambar 16. Area perlindungan Metode Protection Angle pada Tribun Timur

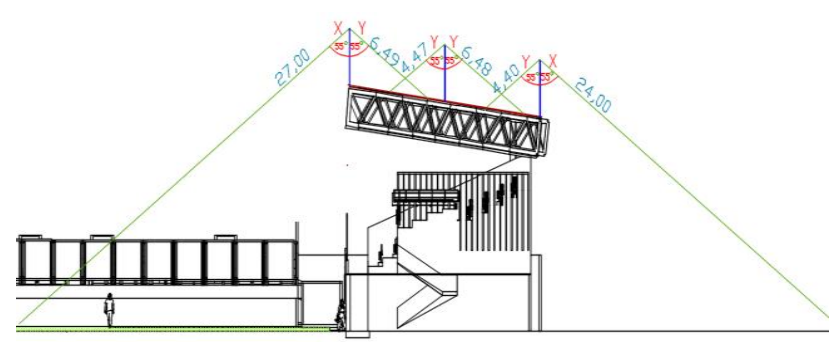

Gambar 17. Area perlindungan Metode Protection Angle pada Tribun Timur sisi lebar

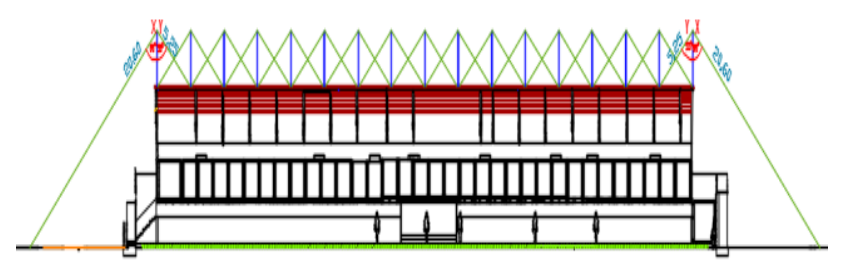

Gambar 18. Area perlindungan Metode Protection Angle pada Tribun Selatan

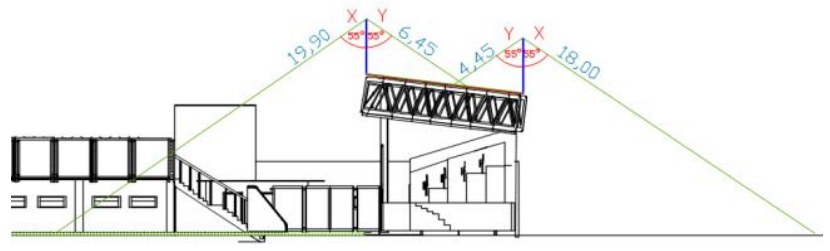

Gambar 19. Area perlindungan Metode Protection Angle pada Tribun Selatan sisi lebar

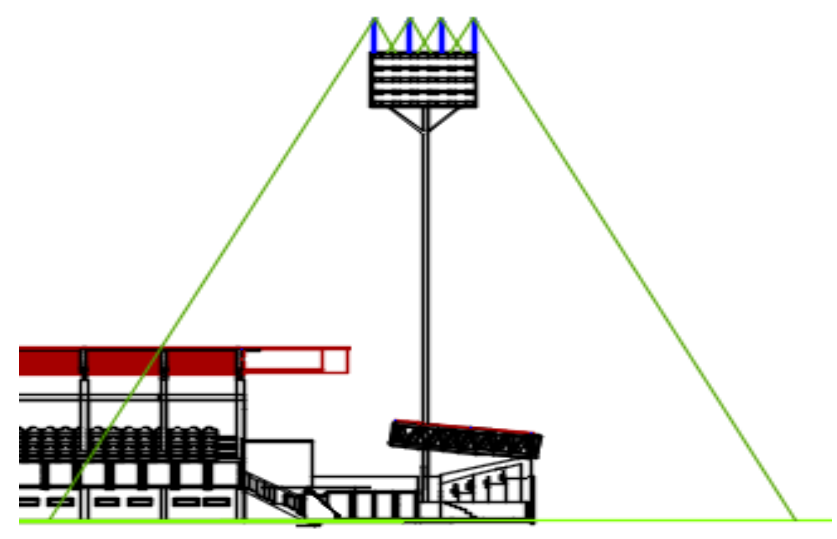

Gambar 20. Area perlindungan Metode Protection Angle pada Tiang lampu

Berdasarkan hasil perancangan metode protection angle pada tribun barat dan tribun timur membutuhkan penambahan 24 air terminal dengan sudut perlindungan sebesar $55^{\circ}$, untuk dapat melindungi seluruh bagian bangunan. Sedangkan pada, hasil perancangan metode protection angle pada tiang lampu sudah sesuai perhitungan dimana dengan 4 air terminal dan sudut perlindungan sebesar $25^{\circ}$, area bangunan dan tiang lampu Stadion Citarum telah terlindungi dan memenuhi SNI 037015-2004.

\subsection{Perancangan Sistem Proteksi Petir Eksternal dengan Metode Mesh}

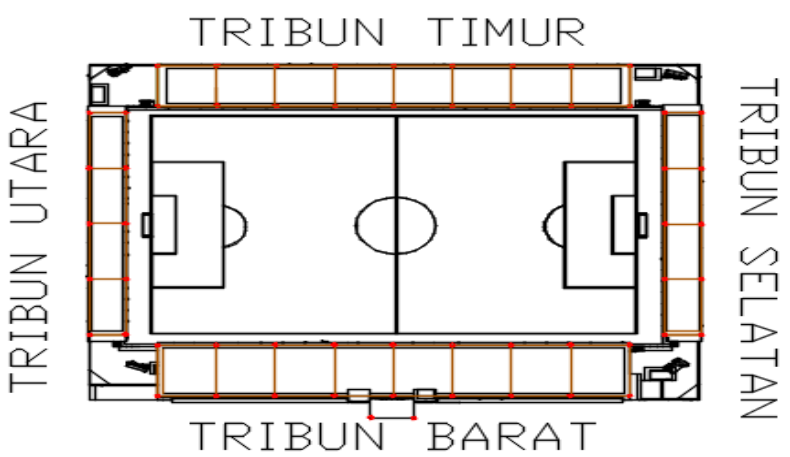

Gambar 21. Metode Mesh 
Ukuran jala yang dipakai dalam penerapan metode jala ini adalah $20 \mathrm{~m}$ x $20 \mathrm{~m}$. Jala - jala konduktor yang dipasang membagi 8 bagian atap pada atap tribun barat dan tribun timur dan membagi 5 bagian pada atap tribun selatan dan tribun utara. Dimensi gedung dapat di lihat bahwa penempatan jala-jala pada metode mesh dengan menempatkan konduktor disetiap titik yang daapt disentuh oleh bola dari metode Rolling Sphere.

\subsection{Perbandingan Metode Rolling Sphere, Protection Angle, dan Mesh}

Berdasarkan simulasi yang telah dilakukan menggunakan software AutoCAD 2016 dapat diketahui bahwa metode Rolling Sphere ini dapat diterapkan untuk semua jenis desain bangunan, baik sederhana maupun rumit untuk menentukan daerah-daerah bangunan yang memerlukan perlindungan. Sedangkan metode sudut perlindungan adalah metode yang terbatas penggunaannya pada evaluasi tingkat efektivitas sistem perlindungan petir yang telah didesain. Metode Protection Angle tidak efisien penerapannya jika panjang area bangunan yang dilindungi lebih dari radius Rolling Sphere. Sedangkan metode Mesh merupakan metode yang memberikan perlindungan pada bangunan dengan kemungkinan bahwa daerah pinggir dan sudut adalah daerah yang paling besar kemungkinannya untuk tersambar petir, maka dilakukan penempatan jala konduktor di sepanjang bangunan sebagai usaha untuk melindungi seluruh daerah tersebut.

\subsection{Perhitungan dan Analisis Gelombang Tegangan Berjalan pada Sistem Proteksi Petir Internal}

Perhitungan besar gelombang tegangan berjalan yang akan masuk ke masing - masing beban dimulai dari sisi sumber 220/380 volt hingga sisi SDP dari lantai 1 hingga 15. Perhitungan mula - mula melakukan perhitungan $\mathrm{Z}$ ekivalen (Z2') dari cabang salah satu MDP dan gelombang tegangan berjalan yang masuk ke SDP. Perhitungan dimulai dari sisi MDP setelah itu sisi SDP pada tiap pelayanan dari lantai 1 hingga 15 . Berikut ini ditunjukkan salah satu proses perhitungan gelombang tegangan berjalan yang masuk pada panel MDP

$$
\begin{aligned}
-\quad \text { Koefisien terusan } \\
v_{2}=\frac{2 Z_{0}}{Z_{0+} Z_{1}} \\
v_{2}=\frac{2 \times 5000}{5482,2} \\
v_{2}=1,824
\end{aligned}
$$

Puncak gelombang yang diteruskan melalui belitan trafo pada sisi tegangan tinggi dengan nilai tegangan impuls petir sebesar $125 \mathrm{kV}$

$$
\begin{aligned}
& V p t=T \times v_{i} \\
& V p t=1,824 \times 125 \mathrm{kV} \\
& V p t=228 \mathrm{kV}
\end{aligned}
$$

Maka tegangan surja yang akan merambat pada belitan sisi tegangan rendah memiliki nilai puncak gelombang sebesar,

$$
\begin{aligned}
V s t & =\frac{400}{20000} \times V p t \\
V s t & =\frac{400}{20000} \times 228 \\
V s t & =4,56 \mathrm{kV}
\end{aligned}
$$

Perhitungan besar gelombang tegangan berjalan yang akan masuk ke masing masing panel SDP adalah sebagai berikut.

- $\quad$ Perhitungan pada sisi MDP menuju lima SDP

$$
\begin{aligned}
\mathrm{n} & =6 \\
T & =\frac{2}{n} \\
T & =\frac{2}{6} \\
T & =0,33
\end{aligned}
$$

Dari perhitungan sebelumnya didapatkan nilai tegangan berjalan yang masuk ke panel MDP sebesar 4,56 kV. Sehingga tegangan yang masuk dari sisi MDP menuju ke lima SDP adalah sebaga berikut

$$
\begin{aligned}
& e_{1}^{\prime \prime}=T \cdot v_{i} \\
& e_{1}^{\prime \prime}=0,33 \cdot 4,56 \\
& e_{1}^{\prime \prime}=1,52 \mathrm{kV}
\end{aligned}
$$

Gelombang tegangan berjalan yang masuk ke lima panel SDP cukup besar dan berbahaya, sehingga diperlukan proteksi dengan pemasangan Surge Arrester Protection (SPD) pada panel MDP dan SDP. Karena pemasangan arrester terletak pada panel distribusi maka Klasifikasi SPD Kelas II yang dipilih dimana sesuai dengan lokasi pemasangan. Pada umumnya SPD kelas II bekerja pada tegangan residu sebesar $1,1 \mathrm{kV}$, hal ini sudah sesuai dengan standar, dimana tegangan residu yang masuk ke peralatan nilainya tidak boleh melebihi BIL peralatan. BIL pada jaringan tegangan rendah bernilai $2 \mathrm{kV}$ yang mengacu pada standar SNI 04-7021.21-2004. Sehingga selisih BIL peralatan dapat diperoleh dengan perhitungan sebagai berikut.

$$
\begin{aligned}
& E=B I L \text { peralatan- Vresidu } \\
& E=2000-1100 \\
& E=900 \text { volt }
\end{aligned}
$$

Maka didapatkan margin arrester untuk peralatan adalah $45 \%$ dari BIL peralatan yang dilindungi. Jika margin arrester bernilai $<20 \%$ dari BIL peralatan yang dilindungi, dapat membahayakan peralatan.

\subsection{Perbandingan Metode Rolling Sphere, Protection Angle, dan Mesh}

Kebutuhan air terminal dengan menggunakan metode Protection Angle memiliki selisih cukup jauh antara hasil perhitungan dan simulasi pada tribun Barat, Utara, Timur dan selatan. Hal ini dikarenakan cakupan area perlindungan dari metode Protection Angle yang sempit 
dan daerah yang dilindungi memiliki panjang lebih dari radius Rolling Sphere sehingga memerlukan banyak air terminal untuk dapat melindungi keseluruhan bagian bangunan. Namun, pada tiang lampu antara hasil perhitungan dan simulasi sudah sesuai dengan 4 Air Terminal sudah dapat melindungi tiang lampu, hal ini dikarenakan panjang tiang lampu yang tidak melebihi radius Rolling Sphere.

\section{Kesimpulan}

Berdasarkan simulasi sistem proteksi eksternal yang telah dilakukan menggunakan software AutoCAD 2016 dapat diketahui bahwa metode Rolling Sphere ini dapat diterapkan untuk semua jenis desain bangunan, baik sederhana maupun rumit untuk menentukan daerah-daerah bangunan yang memerlukan perlindungan. Sedangkan metode sudut perlindungan adalah metode yang terbatas penggunaannya pada evaluasi tingkat efektivitas sistem perlindungan petir yang telah didesain. Metode Protection Angle tidak efisien penerapannya jika panjang area bangunan yang dilindungi lebih dari radius Rolling Sphere. Sedangkan metode Mesh merupakan metode yang memberikan perlindungan pada bangunan dengan kemungkinan bahwa daerah pinggir dan sudut adalah daerah yang paling besar kemungkinannya untuk tersambar petir, maka dilakukan penempatan jala konduktor di sepanjang bangunan sebagai usaha untuk melindungi seluruh daerah tersebut. Sedangkan pada Sistem Proteksi Petir Internal Gelombang tegangan berjalan yang masuk ke lima panel SDP bernilai $1,52 \mathrm{kV}$. Sehingga diperlukan pemasangan Surge Arrester Protection (SPD) kelas II. Margin arrester untuk peralatan adalah $45 \%$ dari BIL peralatan yang dilindungi. Jika margin arrester bernilai $<20 \%$ dari BIL peralatan yang dilindungi, dapat membahayakan peralatan.

\section{Referensi}

[1]. A. D. Hermawan, "Optimalisasi Sistem Penangkal Petir Eksternal Menggunakan Jenis Early Streamer," Universitas Indonesia, Depok, 2010.

[2]. J. Ginting, "ANALISA EFEK TEGANGAN INDUKSI KARENA SAMBARAN PETIR PADA AREA OPERASIONAL PT . X,” Universitas Indonesia, 2012.

[3]. BMKG Stasiun Geofisika Banjarnegara

[4]. R. Zoro, "Induksi dan Konduksi Gelombang Elektromagnetik Akibat Smbaran Petir pada Jaringan Tegangan rendah," Makara, Teknol., vol. 13, no. 1, pp. 25-32, 2009.

[5]. BSN, "Sistem Proteksi Petir pada Bangunan Gedung SNI 03-7015-2004," 2004.

[6]. SNI 04-7021.2.1-2004

[7]. IEC, "IEC 62305-3 Protection against lightning - Part 3: Physical damage to structures and life hazard colour," 2010, $2.02010-1$.

[8]. IEC, "IEC 1024-1-1 Protection of strucures against lightning," 1993. 